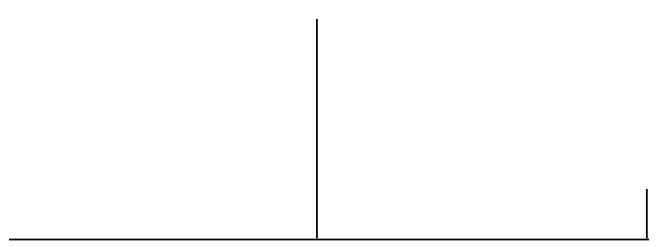

Rev. Latinoam. Psicopat. Fund., São Paulo, v. 13, n. 1, p. 135-136, março 2010

\title{
First lines of the practice of physic (1785)
}

William Cullen ${ }^{1}$

\section{Part II \\ Of neuroses, or nervous diseases}

1090. IN a certain view, almost the whole of the diseases of the human body might be called NERVOUS; but there would be no use for such a general appellation; and, on the other hand, it seems improper to limit the term, in the loose inaccurate manner in which it has been hitherto applied, to hysteric or hypochondriacal disorders, which are themselves hardly to be defined with sufficient precision.

1091. In this place, I propose to comprehend, under the title of NEUROSES, all those preternatural ${ }^{2}$ affections of sense or

1. William Cullen (1785). First Lines of the Practice of Physic. (New Edition), v. 2. Edimburgh, 1808.

Site: http://books.google.com/books?id=emkFAAAAQAAJ7pg=PR4\&dq=Cullen+ First+Lines+in+the+Practice+of+Physic \&Ir=\&hl=pt-BR\&output=text

2. Sobre a noção de "preternaturais", ver Saurí, J., "A construção do conceito de neurose (II). Nosologia e neurose", Revista Latinoamericana de Psicopatologia Fundamental, v. VIII, n. 2, p. 289-302, jun.2005. 
motion which are without pyrexia, as a part of the primary disease ; and all those which do not depend upon a topical affection of the organs, but upon a more general affection of the nervous system, and of those powers of the system upon which sense and motion more especially depend. ${ }^{3}$

1092. Of such diseases I have established a class, under the title of NEUROSES or NERVOUS DISEASES. These I again distinguish, as they consist, either in the interruption and debility of the powers of sense and motion, or in the irregularity with which these powers are exercised; and have accordingly arranged them under the four orders of Comata, Adynamice, Spasmi, and Vesania, to be defined as we proceed to treat of them more particularly.

3. ["Proponho agrupar sob o título de neurose, todas essas afecções preternaturais da sensibilidade e a motricidade nas quais a pirexia não constitui uma parte da enfermidade primária; a todas aquelas que não dependem de alterações locais dos órgãos, mas sim de uma afecção geral do sistema nervoso e das potências de onde dependem mais especificamente a sensibilidade e o movimento"].

\section{Wlliam Cullen (1710-1790)}

Médico escocês, autor de vasta obra médica no campo da nosografia. Propôs pela primeira vez em 1769 o uso técnico do termo "neuroses". 